\title{
Laboratory and field assessments of lethal and sublethal toxicities of acetogenin-based bioinsecticides against Zaprionus indianus (Diptera: Drosophilidae)
}

\author{
Fernanda C.S. Geisler ${ }^{1}$, Liliane N. Martins ${ }^{1}$, Rute C.B. Treptow ${ }^{1}$, Cléber A. Baronio ${ }^{1}$, Paloma Stupp ${ }^{1}$, \\ Leandro P. Ribeiro ${ }^{2}$, Flávio R.M. Garcia ${ }^{1}$, and Daniel Bernardi ${ }^{1 *}$ \\ 'Universidade Federal de Pelotas, Pelotas, Rio Grande do Sul, 96010900, Brasil. \\ "Corresponding author (dbernardi2004@yahoo.com.br). \\ ${ }^{2}$ Empresa de Pesquisa Agropecuária e Extensão Rural de Santa Catarina, Chapecó, Santa Catarina, 89801-970, Brasil.
}

Received: 30 January 2019; Accepted: 30 May 2019; doi:10.4067/S0718-58392019000400501

\begin{abstract}
Neotropical Annonaceae-derived bioinsecticides have shown promising control of insect pest species. In order to develop an alternative tool for control Zaprionus indianus (Gupta, 1970), an important invasive pest of Brazilian orchards, this study investigated the insecticidal activity of a formulation prepared from ethanolic seed extract of different Annona species (Annona mucosa Jacq., Annona muricata L., and Annona sylvatica A. St.-Hil.) at discriminatory concentration of $2000 \mathrm{mg} \mathrm{L}^{-1}$ in comparison with a limonoid-based bioinsecticide and a synthetic insecticide (spinetoram) as positive controls. In an ingestion and topical application bioassay, the formulation based on A. mucosa caused more than 95\% mortality, which was equivalent to the mortality caused by the synthetic insecticide spinetoram. In a free-choice bioassay, A. mисоsa (83\%), bioinsecticide (88\%) and synthetic insecticide (98\%) produced a significant reduction in the number of eggs per fruit. In addition, formulations based on A. mucosa, A. sylvatica, A. muricata and bioinsecticide resulted in a 50\% reduction in egg viability. In the field, $A$. mисоs $a$ and bioinsecticide negatively influenced the infestation by $Z$. indianus in figs, producing a significant reduction in the number of larvae per fruit (3.6 and 2.29 larvae per fruit, respectively) in relation to the control treatment (11 larvae per fruit). However, they were significantly inferior to the synthetic insecticide (0.71 larvae per fruit). Thus, A. mисоsa, bioinsecticide and spinetoram have the potential to be used in the framework of Z. indianus management.
\end{abstract}

Key words: Fig fly, Annonaceae, rolliniastatin-1, sustainable pest management.

\section{INTRODUCTION}

The fig fly, Zaprionus indianus (Gupta, 1970) (Diptera: Drosophilidae), has high adaptability and a short developmental period. The high biotic potential of $Z$. indianus has resulted in a fast distribution and adaptation of the pest in Brazil and several fig (Ficus carica L., Moraceae) producing regions, including Uruguay, Central America, Europe (Commar et al., 2012), and North America (Joshi et al., 2014; Lasa and Tadeo, 2015). Zaprionus indianus females cause damage by oviposition in the ostiolar region of the fruit and, after hatching, the larvae penetrate the fruit, making it unfit for consumption and commercialization (Joshi et al., 2014; Lasa and Tadeo, 2015).

Fig is a widely cultivated species, especially in regions with a semi-arid climate where there is irrigation, with an annual world production of approximately one million tons, and is mainly concentrated in the Mediterranean. In Brazil, fig crops are widely grown on small farms, especially in the South and Southeast regions, and there is a high demand 
from import markets, especially Holland, France and Germany (Commar et al., 2012). However, one of the leading technological limitations of the crop, which has made it difficult to obtain higher yields and profitability, is the occurrence of the fig fly, Z. indianus (Pasini et al., 2011). One of the main strategies adopted for the management of Z. indianus in Brazilian orchards is the application of styrofoam protectors (Raga et al., 2003). Although efficient in reducing infestation and fruit damage, this technique demands a large workforce and time (Raga et al., 2003).

Therefore, farmers resort to using synthetic insecticides in an emergency when conditions of high pest infestations occur, even though there are no registered products for the crop in Brazil. Efficient and environmentally appropriate strategies have been one of the targets of tropical and temperate fruit production systems and Integrated Pest Management (IPM) programs in general. In this context, the use of botanical insecticides has been an essential alternative to synthetic pesticides in integrated production programs (Isman and Grieneisen, 2014). Given this potential and the great diversity of botanical species with a potential insecticide present in the tropical flora, screening studies have been carried out in Brazil aiming to identify new compounds and new sources of botanical insecticides that can be used to protect crops (Ribeiro et al., 2016).

Among the derivatives of tropical plant species with insecticidal potential, crude and semipurified extracts of Annonaceae have demonstrated great potential in the management of different pest arthropods in different production systems (Ribeiro et al., 2013; Goncalves et al., 2015; Bernardi et al., 2017a). The insecticidal/insectistatic activity of Annonaceae derivatives is attributed in particular to the presence of structurally diverse acetogenins in their composition, a class of natural compounds found exclusively in some genera of this botanical family (Ribeiro et al., 2013). In addition to the lethal effects, the deterrent effects of the feeding and oviposition can be caused by derivatives rich in acetogenins or isolated compounds (Ribeiro et al., 2015; Bernardi et al., 2017a), which is compatible with IPM (Hikal et al., 2017) and biological control (Ribeiro et al., 2014; Bernardi et al., 2017a).

To date, no study has been conducted to evaluate the effect of botanical extracts on Z. indianus. However, botanical insecticides based on acetogenins have demonstrated high toxicity on Drosophila species such as D. suzukii (Diptera: Drosophilidae) (Bernardi et al., 2017a), as well as azadirachtin-based formulations on D. melanogaster (Diptera: Drosophilidae) (Oulhaci et al., 2018). Due to that potential, which has been demonstrated in laboratory and field trials, the present study aimed to evaluate the lethal toxicity of formulations of ethanolic extracts obtained from seeds of preselected species of neotropical Annona (Annona mucosa Jacq., Annona muricata L., and Annona sylvatica A. St.-Hil.), compared to a commercial insecticide of natural origin (limonoids derived from neem, Azadirachta indica A. Juss.) and a synthetic insecticide (spinetoram) in the management of Z. indianus. Also, tests were carried out to evaluate the effect of these treatments on oviposition and embryonic development (ovicidal effect) of $Z$. indianus in artificial fruits.

\section{MATERIALS AND METHODS}

\section{Annonaceous derivatives: sources, crude extract preparation and formulation procedures}

Detailed information on the origin of Annona species used in this study (Table 1) is found in Voucher specimens, previously identified by Prof. Dr. Renato Mello-Silva (Department of Botany, Biosciences Institute/University of São Paulo [IB/ USP]), which were deposited in the herbarium of the Department of Biological Sciences at "Luiz de Queiroz" College of Agriculture/University of São Paulo, Piracicaba Municipality, São Paulo State, Brazil, under the registered numbers 120985 (A. mucosa), 121205 (A. sylvatica) and 121892 (A. muricata). For crude extract preparation, seeds collected from ripe fruits were oven-dried at $38^{\circ} \mathrm{C}$ for $48 \mathrm{~h}$ and then milled to a powder in a knife mill. Powders were stored in sealed glass containers and stored at approximately $-10{ }^{\circ} \mathrm{C}$ until use. Organic extracts were obtained by cold maceration using analytical grade ethanol as a solvent $(5: 1 \mathrm{v} / \mathrm{v})$, with the seed powder stored in ethanol for $3 \mathrm{~d}$, followed by filtering through filter paper. This process was repeated three times. The remaining solvent was removed in vacuo at $50{ }^{\circ} \mathrm{C}$. After complete evaporation of the solvent in an airflow chamber, the extraction yield for each species was determined. For preparation of aqueous emulsified formulations, the ethanolic seed-extracts were solubilized in the organic solvents acetone:methanol $(1: 1 \mathrm{v} / \mathrm{v})$ at $100 \mathrm{~g} \mathrm{~L}^{-1}$, with subsequent addition of Tween 80 emulsifier at $10 \mathrm{~g} \mathrm{~L}^{-1}$.

\section{Tested insects}

Zaprionus indianus used in the bioassays were obtained from a colony established from specimens collected from a strawberry

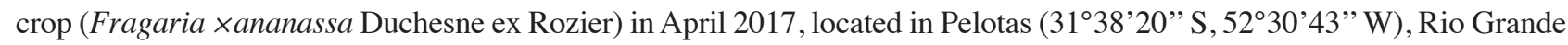


Table 1. Treatments evaluated for the management of Zaprionus indianus.

\begin{tabular}{|c|c|c|c|}
\hline Treatments & Description & Concentration tested $^{\mathrm{a}}$ & Origin/manufacturer \\
\hline EES Annona тисоsa & $\begin{array}{l}\text { Aqueous emulsion of ethanolic seed extract of A. тисоs } \\
\text { (pre-commercial) }\end{array}$ & $2000 \mathrm{~mL} \mathrm{~L}^{-1^{*}}$ & -- \\
\hline EES A. muricata & $\begin{array}{l}\text { Aqueous emulsion of ethanolic seed extract of A. muricata } \\
\text { (pre-commercial) }\end{array}$ & $2000 \mathrm{~mL} \mathrm{~L}^{-1^{*}}$ & -- \\
\hline EES A. sylvatica & $\begin{array}{l}\text { Aqueous emulsion of ethanolic seed extract of A. sylvatica } \\
\text { (pre-commercial) }\end{array}$ & $2000 \mathrm{~mL} \mathrm{~L}^{-1^{*}}$ & -- \\
\hline Azamax 12 EC & $\begin{array}{l}\text { Limonoid-based biopesticide [azadirachtin }\left(6220.15 \mathrm{mg} \mathrm{L}^{-1}\right) \\
\text { + 3-tigloylazadirachtol }\left(2596 \mathrm{mg} \mathrm{L}^{-1}\right) \text { ] extracted and purified } \\
\text { from Azadirachta indica seeds }\end{array}$ & $\begin{array}{l}3.0 \mathrm{~mL} \mathrm{~L}^{-1} \text { (recommended } \\
\text { by the manufacturer) }\end{array}$ & $\begin{array}{l}\text { UPL Brasil (Campinas, } \\
\text { São Paulo, Brazil) }\end{array}$ \\
\hline Delegate 250WG & Spinetoram $^{a}$ & $\begin{array}{l}75 \mathrm{~g} \text { ai } 100 \mathrm{~L}^{-1} \\
\text { (recommended by the } \\
\text { manufacturer) }\end{array}$ & $\begin{array}{l}\text { Dow AgroSciences } \\
\text { Industrial Ltda, São Paulo, } \\
\text { SP, Brazil }\end{array}$ \\
\hline
\end{tabular}

aConcentration: $\mathrm{g}$ or $\mathrm{mL}$ commercial product $100 \mathrm{~L}^{-1}$ water.

"The concentration $2000 \mathrm{~mL} \mathrm{~L}^{-1}$ was used for each extract formulated according to the type of bioassay (oviposition deterrence effect, ovicidal action or field effectiveness). EES: Formulated ethanolic seed extract.

do Sul State, Brazil, and kept in the laboratory for approximately the $15^{\text {th }}$ generation without pressure of selection by insecticides. For insect rearing, infested strawberry fruits were placed in a thermal box and sent to the laboratory where they were weighed and individually placed in plastic pots $(150 \mathrm{~mL})$ with a perforated lid $(2 \mathrm{~cm}$ in diameter) and covered with voile fabric containing a thin layer of vermiculite $(1 \mathrm{~cm})$. The fruits were kept in an air-conditioned room at $23 \pm 2$ ${ }^{\circ} \mathrm{C}, 70 \pm 10 \% \mathrm{RH}$ and 12:12 h photoperiod until adult emergence. Subsequently, flies (male and female) were transferred to a flat-bottomed glass container $(8.5 \mathrm{~cm}$ high by $2.5 \mathrm{~cm}$ in diameter) containing artificial diet $(8 \mathrm{~mL})$, consisting of corn flour, sugar and yeast (Schlesener et al., 2017).

\section{Laboratory bioassays}

All laboratory bioassays were performed under controlled conditions $\left(25 \pm 2{ }^{\circ} \mathrm{C}, 70 \pm 10 \% \mathrm{RH}\right.$ and a $12: 12 \mathrm{~h}$ photoperiod $)$ using a completely randomized design. The treatments and discriminatory concentrations used are detailed in Table 1 . The formulation based on spinetoram (7.5 mg ai L-1; Delegate 250WG, Dow AgroSciences, Santo Amaro, São Paulo, Brazil) and the limonoid-based bioinsecticide (azadirachtin + 3-tigloil-azadiractol, 1.2 $\mathrm{mL}$ ai L-1; Azamax 1.2 EC, UPL Brasil, Campinas, São Paulo, Brazil) were used as positive controls (Table 1).

\section{Discriminatory tests (initial screening)}

In order to assess the lethal toxicity of the formulated annonaceous derivatives, initial tests were performed using the discriminatory concentration of $2000 \mathrm{mg} \mathrm{L}^{-1}$ on Z. indianus adults (Table 1). For this purpose, we used ingestion and topical application bioassays. For the ingestion bioassays, insects were separated into groups (sample units) of 20 adults of Z. indianus (8-d-old) and placed inside cages made from clear plastic cups (1 L) and flipped upside-down on a plastic petri dish ( $25 \mathrm{~cm}$ in diameter) and sealed on top (cup bottom) with a voile mesh for ventilation. After preparation of appropriate dilutions, the products were offered to the insects by capillarity in cotton wool rolls inside $10-\mathrm{mL}$ glass vials for $24 \mathrm{~h}$. After this period, food and distilled water replaced the glass tubes with treated cotton until the end of the evaluation period, according to the method described by Schlesener et al. (2017). Mortality was evaluated for up to $120 \mathrm{~h}$ after the beginning of treatment. In both experiments, flies were considered to be dead when no movement occurred after touching with a fine brush. For each treatment, we used four replicates each composed of 20 flies $(n=80)$.

In the topical application bioassay, the insects were divided into groups of $10 \mathrm{Z}$. indianus adults (8-d-old) inside clear glass test tubes $(2.5 \mathrm{~cm}$ in diameter $\times 8 \mathrm{~cm}$ in length) sealed with a cotton plug. Spraying was carried out by, firstly, sedating insects by placing the glass test tubes in the freezer for 30 to $40 \mathrm{~s}$ and then placing the insects in a glass Petri dish $(9 \mathrm{~cm}$ in diameter) lined with filter paper. The insects were then sprayed using a Precision Laboratory Spray Tower (Burkard Scientific, Uxbridge, UK), applying $1 \mathrm{~mL}$ of spray solution per sample unit at a working pressure of $0.049 \mathrm{MPa}$, resulting in an average residue deposition of $3 \mathrm{mg} \mathrm{cm}^{-2}$. After spraying, the insects were carefully placed inside clear plastic cup cages $(100 \mathrm{~mL})$ sealed with a venting lid (a voile mesh-sealed opening in the cup lid). Inside these cages, 
flies were provided with liquid food and water until the end of the evaluation period, according to the method described by Bernardi et al. (2017b). Mortality was evaluated for up to $120 \mathrm{~h}$ after the beginning of the treatment as described previously. For each treatment, we used 10 replicates with 10 flies in each $(n=100)$.

Based on initial screening, the most promising treatments were selected and submitted to a new bioassay in order to estimate the concentration required to kill $50 \%$ and $90 \%$ of exposed flies $\left(\mathrm{LC}_{50}\right.$ and $\mathrm{LC}_{90}$, respectively). For this purpose, seven concentrations (125-4000 mg L $\mathrm{m}^{-1}$ for the A. mucosa formulated extract, and 10-100 $\mathrm{mg} \mathrm{L}^{-1}$ for spinetoram) were defined for each insecticide and the mode of exposure based on the procedure proposed by Finney (1971). The exposure and evaluation procedures, as well the mortality criteria, were the same as those used in the initial tests. In the ingestion bioassays, four replicates each comprising 20 flies $(n=80)$ for each concentration of each insecticide were used. In the topical application bioassays, 10 replicates each comprising 10 flies $(n=100)$ were used for each concentration of each insecticide tested.

\section{Oviposition deterrence assessment}

To assess the effect of treatments on female oviposition behavior, flies were submitted to choice and no-choice oviposition bioassays. For this purpose, artificial fruits were prepared with agar (19 g), raspberry gelatin (10 g), methylparaben (Nipagin, Vetec, Química Finz, Duque de Caxias, Río de Janeiro, Brazil) $8 \mathrm{~mL}$ ( $0.8 \mathrm{~g}$ dissolved in $8 \mathrm{~mL} 99.9 \%$ absolute ethyl alcohol) and distilled water (refluxed; $850 \mathrm{~mL}$ ), in accordance with the adapted method proposed by Schlesener et al. (2017).

For the no-choice oviposition bioassay, artificial fruits were dipped in the treatment solutions (Table 1) for $5 \mathrm{~s}$. Later, they were dried on filter paper for $3 \mathrm{~h}$ and then each artificial fruit (sample unit) was placed inside a cage (clear 1000-mL plastic cups inverted on a Petri dish, $8 \mathrm{~cm}$ in diameter) containing ten 8-d-old Z. indianus flies (five pairs) for oviposition. In the free-choice oviposition bioassay, the experiment was conducted in semi-transparent plastic cages under the same conditions described for the no-choice bioassay. Later, two artificial fruits (untreated and treated) were placed inside each cage containing two 5-d-old pairs of Z. indianus flies for oviposition, as described above. The artificial fruits were placed equidistant from each other. In both types of oviposition bioassays, after artificial fruits exposed for $24 \mathrm{~h}$, the adults were removed and the eggs in the artificial fruit were counted with the aid of a stereoscopic microscope (40X; Série NO106; Global Optics, Monte Alto, São Paulo, Brazil). In each type of bioassay, we used 30 replicates per treatment.

\section{Ovicidal effects}

To obtain Z. indianus eggs, an artificial fruit was placed inside the cage (clear plastic $200-\mathrm{mL}$ cups inverted on a Petri dish [8 $\mathrm{cm}$ in diameter]) containing ten 8-d-old flies (five pairs) of Z. indianus to serve as an oviposition substrate. After $24 \mathrm{~h}$ of oviposition, artificial fruits contained $Z$. indianus eggs were dipped in the treatments (Table 1) for $5 \mathrm{~s}$ and then were left to dry on filter paper for $3 \mathrm{~h}$. After this period, the artificial fruits were individually packed inside $200-\mathrm{mL}$ plastic cups on a sheet of filter paper ( $3 \mathrm{~cm}$ in diameter), which were closed at the top with its respective lid and kept in an air-conditioned room as previously described. The number of larvae hatching was counted using a stereoscopic microscope (40X) after 3 $\mathrm{d}$, the time required for larvae to hatch. For each treatment, 30 replicates were used.

\section{Efficacy under field conditions (commercial fig orchard)}

The efficacy of the formulated A. mисоs $a$ at $2000 \mathrm{~mL} \mathrm{~L}^{-1}$ compared with a limonoid-based bioinsecticide (Azamax 1.2 EC) and a spinetoram-based synthetic insecticide (Delegate $250 \mathrm{WG)}$ ) were also evaluated in a commercial fig orchard ('Roxo de Valinhos'; approximately 5-yr-old trees) with plants grown with $2.5 \times 5 \mathrm{~m}$ spacing (between plants and between rows, respectively), also located in Pelotas $\left(31^{\circ} 42^{\prime} 20^{\prime \prime} \mathrm{S}, 52^{\circ} 27^{\prime} 31^{\prime \prime} \mathrm{W}\right)$. No pesticide spraying took place in this orchard before the start of the experiment. The treatments were applied at weekly intervals over a 4-wk period, with the first application of treatment at the beginning of fruit formation. The applications were carried out using a $5 \mathrm{~L}$ capacity spray (PJH model Jacto, Pompéia, São Paulo, Brazil), equipped with an empty cone-type nozzle (model JA-1,5; Máquinas Agrícolas Jacto S.A, Pompéia, SP, Brazil). The treatments were sprayed to saturation (volume of syrup was approximately $500 \mathrm{~L} \mathrm{ha}^{-1}$ ), with the jets directed toward the fruits. The experimental design was completely randomized with five replicates per treatment, and each replicate was composed of one plant. The evaluation of the natural infestation of Z. indianus was carried out in the fruit harvesting period using the random selection of 10 ripe fig fruits per plant, totaling 50 fruits per treatment. The variables analyzed were percentage of fruits infested by $Z$. indianus larvae and average number of $Z$. indianus larvae per fruit. 


\section{Statistical analyses}

For the analyses of studied variables, we used generalized linear models (GLM) of the exponential family of distributions. The verification of quality adjustment was performed through the half-regular graph odds with simulation envelope. When significant differences were detected between treatments, multiple comparisons (Tukey's test, $\mathrm{P}<0.05$ ) were performed using the glht function of the Multicomp package (R statistical software version 2.15.1), with adjustment of P-values. For comparisons of the average of two treatments in the oviposition bioassay (choice test), we used the Student's t-test. All analyses were performed using R statistical software (R Development Core Team, 2012). A binomial model with a complementary log-log link function (gompit model) was used to estimate the lethal concentrations $\left(\mathrm{LC}_{50}\right.$ and $\mathrm{LC}_{90}$ ) using the Probit Procedure in the SAS statistical software package version 9.2 (SAS Institute, 2011).

\section{RESULTS}

\section{Toxicities and concentration-response curves of the active treatments}

After $120 \mathrm{~h}$ of exposure, the A. mucosa formulation (2000 mg L-1) and spinetoram ( $\left.75 \mathrm{mg} \mathrm{L}^{-1}\right)$ showed high toxicity, with levels of fig fly mortality greater than $90 \%$ via ingestion and/or by topical application (Figure 1 ). These values were significantly higher (topical application $\left[\mathrm{F}_{6,21}=60.101 ; \mathrm{P}<0.0001\right.$ ) $]$; ingestion $\left[\mathrm{F}_{6,21}=55.517 ; \mathrm{P}<0.0001\right]$ ) than those of formulations prepared from A. sylvatica and A. muricata seeds or the limonoid-based bioinsecticide, which caused mortalities of between $40 \%$ and $60 \%$, both in the ingestion bioassay and with topical application (Figure 1). Based on concentration-response curves for the ingestion bioassay, the toxicity of the $A$. mucosa formulation was lower $\left(\mathrm{LC}_{50}=\right.$ $\left.454.45 \mathrm{mg} \mathrm{L}^{-1}\right)$ than spinetoram $\left(\mathrm{LC}_{50}=15.12 \mathrm{mg} \mathrm{L}^{-1}\right)$ at $120 \mathrm{~h}$ (Table 2). Likewise, in relation to $\mathrm{LC}_{90}$ values, the toxicity of A. mucosa was lower than spinetoram; $\mathrm{LC}_{90}$ values were 1553.4 and $68.67 \mathrm{mg} \mathrm{L}^{-1}$, respectively, at $120 \mathrm{~h}$ after exposure to toxic baits (Table 2). Regardless of treatments, the levels of mortality were concentration-dependent with significantly increased mortality throughout the exposure period. In the topical application bioassays, the estimated $\mathrm{LC}_{50}$ at $120 \mathrm{~h}$ for spinetoram-based insecticide was significantly lower $\left(\mathrm{LC}_{50}=16.06 \mathrm{mg} \mathrm{L}^{-1}\right)$ than observed with A. mucosa $\left(\mathrm{LC}_{50}=389.13\right.$ $\left.\mathrm{mg} \mathrm{L}^{-1}\right)$ (Table 3). In relation to $\mathrm{LC}_{90}$ values, the toxicity of spinetoram $\left(\mathrm{LC}_{90}=45.78 \mathrm{mg} \mathrm{L}^{-1}\right)$ was higher than $A$. mucosa $\left(\mathrm{LC}_{90}=1457.7 \mathrm{mg} \mathrm{L}^{-1}\right)$ at $120 \mathrm{~h}$ after application (Table 3). Again, the mortality levels increased significantly throughout the exposure period.

Figure 1. Percentage mortality $( \pm \mathrm{SE})$ of Zaprionus indianus at $120 \mathrm{~h}$ after exposure to different treatments in laboratory bioassays.

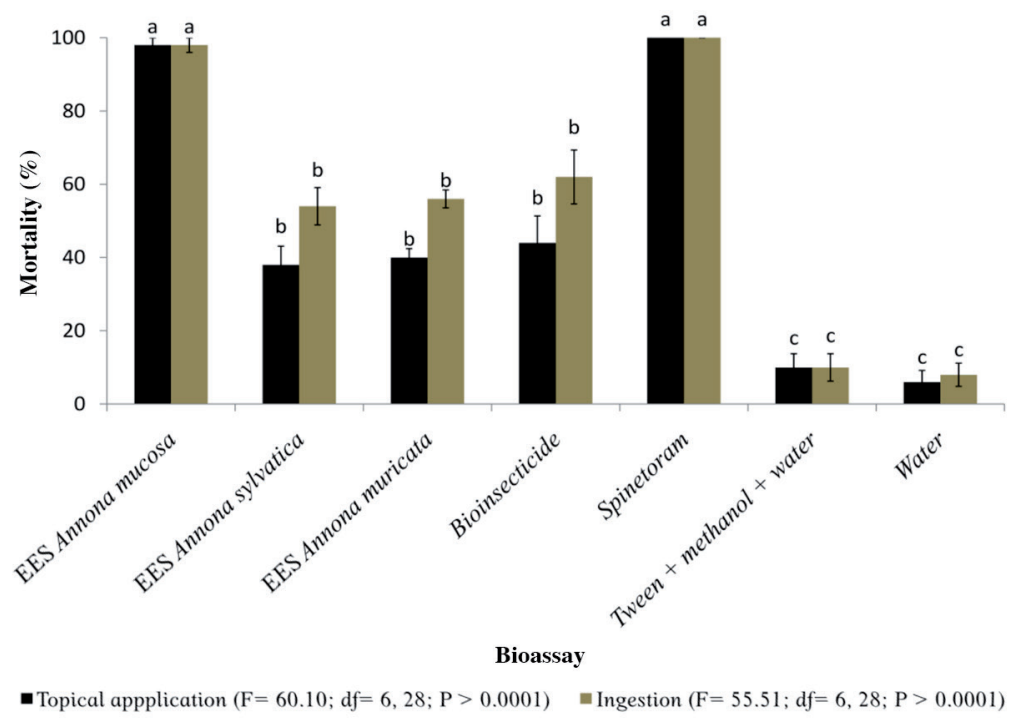

Means followed by distinct letters in columns (with the same exposure method) indicate significant differences between treatments (generalized linear models with quasi-binomial distribution followed by Tukey's post hoc test; $\mathrm{P}<0.05)$. EES: Formulated ethanolic seed extract. 
Table 2. Estimate of the $\mathrm{LC}_{50}$ and $\mathrm{LC}_{90}$ and the confidence interval for a formulated ethanolic extract from Annona mucosa seeds and a spinosyn-based synthetic insecticide (spinetoram) in Zaprionus indianus adults with different exposure times in an ingestion bioassay.

\begin{tabular}{clcccccc}
\hline $\begin{array}{c}\text { Exposure time } \\
(\mathrm{h})\end{array}$ & Treatments & $\mathrm{n}$ & Slope $\pm \mathrm{SE}$ & LC $_{50}(\mathrm{CI} 95 \%)$ & LC $_{90}(\mathrm{CI}$ 95\% $)$ & $\chi^{2}$ & $\mathrm{df}$ \\
\hline \multirow{2}{*}{12} & A. mucosa & 560 & $2.61 \pm 0.51$ & $1206.00(996.40-2278.40)$ & $3479.80(1884.60-4434.60)$ & 17.10 & 4 \\
& Spinetoram & 700 & $3.56 \pm 0.40$ & $53.26(30.76-65.61)$ & $150.50(143.07-161.73)$ & 3.57 & 5 \\
24 & A. mucosa & 560 & $2.77 \pm 0.31$ & $932.30(718.32-1126.40)$ & $2528.00(2160.40-3601.50)$ & 7.23 & 4 \\
& Spinetoram & 640 & $2.64 \pm 0.28$ & $46.99(39.09-54.24)$ & $133.90(113.68-167.49)$ & 3.18 & 5 \\
48 & A. mucosa & 560 & $1.36 \pm 0.36$ & $539.39(147.80-2085.10)$ & $3092.30(1996.40-4361.60)$ & 11.54 & 5 \\
& Spinetoram & 640 & $2.18 \pm 0.21$ & $29.96(24.04-35.58)$ & $106.45(89.92-131.93)$ & 6.63 & 5 \\
72 & A. mucosa & 480 & $2.49 \pm 0.25$ & $278.60(270.79-285.75)$ & $2026.80(1856.50-2338.07)$ & 3.97 & 4 \\
& Spinetoram & 640 & $2.19 \pm 0.19$ & $21.37(16.92-25.63)$ & $75.46(64.60-90.92)$ & 7.85 & 5 \\
96 & A. mucosa & 480 & $2.33 \pm 0.22$ & $523.14(431.00-616.42)$ & $1708.30(1405.00-2207.00)$ & 4.96 & 4 \\
& Spinetoram & 640 & $2.75 \pm 0.21$ & $18.37(16.95-21.32)$ & $75.46(64.60-90.92)$ & 7.15 & 5 \\
& A. mucosa & 480 & $2.33 \pm 0.23$ & $454.45(365.44-542.56)$ & $1553.40(1273.00-2016.50)$ & 3.26 & 4 \\
& Spinetoram & 480 & $1.82 \pm 0.22$ & $15.12(11.13-18.93)$ & $68.67(53.31-98.92)$ & 2.81 & 4 \\
\hline
\end{tabular}

$\mathrm{LC}_{50}$ and $\mathrm{LC}_{90}$ : Insecticide concentrations $\left(\mathrm{mg} \mathrm{L}^{-1}\right)$ required to kill $50 \%$ and $90 \%$ of $\mathrm{Z}$. indianus adults, respectively (CI: confidence interval at $95 \%$ error probability); $\chi^{2}$ : Pearson's chi-square value; df: degrees of freedom.

Table 3. Estimate of the $\mathrm{LC}_{50}$ and $\mathrm{LC}_{90}$ as well as the confidence interval of a formulated ethanolic extract from Annona mucosa seeds and a spinosyn-based synthetic insecticide (spinetoram) on Zaprionus indianus adults with different exposure times in a topical application bioassay.

\begin{tabular}{|c|c|c|c|c|c|c|c|}
\hline $\begin{array}{c}\text { Exposure time } \\
(\mathrm{h})\end{array}$ & Treatments & $\mathrm{n}$ & Slope \pm SE & $\mathrm{LC}_{50}(\mathrm{CI} 95 \%)$ & $\mathrm{LC}_{90}(\mathrm{CI} 95 \%)$ & $\chi^{2}$ & df \\
\hline \multirow[t]{2}{*}{12} & A. тисова & 700 & $3.56 \pm 0.40$ & $2326.40(2076.00-2561.40)$ & $5050.40(4393.70-6173.50)$ & 3.57 & 4 \\
\hline & Spinetoram & 567 & $2.72 \pm 0.21$ & $25.16(21.54-28.43)$ & $69.31(62.93-77.68)$ & 6.51 & 7 \\
\hline \multirow[t]{2}{*}{24} & A. mисоsa & 700 & $3.46 \pm 0.32$ & $1654.00(1443.40-1840.50)$ & $3672.60(3305.80-4196.10)$ & 6.16 & 4 \\
\hline & Spinetoram & 525 & $2.76 \pm 0.23$ & $21.00(17.59-24.09)$ & $57.00(51.43-64.12)$ & 8.17 & 6 \\
\hline \multirow[t]{2}{*}{48} & A. mисоsa & 700 & $2.36 \pm 0.42$ & $1083.60(446.65-1552.80)$ & $3480.20(2593.50-6048.10)$ & 9.96 & 4 \\
\hline & Spinetoram & 638 & $2.67 \pm 0.21$ & $18.90(15.19-22.15)$ & $53.15(48.18-59.41)$ & 7.57 & 7 \\
\hline \multirow[t]{2}{*}{72} & A. mисоsa & 600 & $2.05 \pm 0.40$ & $688.57(554.69-818.08)$ & $2642.00(2209.80-3318.40)$ & 1.83 & 4 \\
\hline & Spinetoram & 641 & $2.83 \pm 0.23$ & $17.83(14.36-20.82)$ & $47.29(42.24-54.27)$ & 6.15 & 6 \\
\hline \multirow[t]{2}{*}{96} & A. mucosa & 600 & $1.77 \pm 0.50$ & $516.34(398.14-633.20)$ & $2451.50(1897.50-3524.80)$ & 1.37 & 4 \\
\hline & Spinetoram & 575 & $2.79 \pm 0.48$ & $16.54(13.11-19.50)$ & $44.48(40.12-50.03)$ & 5.25 & 6 \\
\hline \multirow[t]{2}{*}{120} & A. mисоs $a$ & 600 & $2.09 \pm 0.19$ & $389.13(298.96-476.33)$ & $1457.70(1236.40-1767.10)$ & 5.62 & 4 \\
\hline & Spinetoram & 472 & $4.06 \pm 1.14$ & $16.06(11.86-19.42)$ & $45.78(39.87-55.53)$ & 7.03 & 5 \\
\hline
\end{tabular}

$\mathrm{LC}_{50}$ and $\mathrm{LC}_{90}$ : Insecticide concentrations (mg L-1) required to kill $50 \%$ and $90 \%$ of $\mathrm{Z}$. indianus adults, respectively (CI: confidence interval at $95 \%$ error probability); $\chi^{2}$ : Pearson's chi-square value; df: degrees of freedom.

\section{Oviposition deterrent effects}

In a no-choice oviposition bioassay, the dried residues of all treatments significantly reduced $\left(\mathrm{F}_{5,29}=55.721 ; \mathrm{P}<0.0001\right)$ oviposition of Z. indianus on the artificial fruits when compared to the negative controls (Figure 2A), with exception of A. sylvatica formulated extract. Similarly, in the choice bioassay, there were a significantly reduced number of deposited eggs per artificial fruit containing the dried residues of $A$. mucosa formulation $(1.3$ eggs per fruit; $\mathrm{t}=8.36$, $\mathrm{df}=46.02$; $\mathrm{P}<0.0001)$, limonoid-based bioinsecticide $(1.0$ eggs per fruit; $\mathrm{t}=8.0748, \mathrm{df}=32.60 ; \mathrm{P}<0.0001)$ and spinetoram $(0.2$ eggs per fruit; $\mathrm{t}=12.99, \mathrm{df}=30.276 ; \mathrm{P}<0.0001)$ when compared with untreated artificial fruit (Figure $2 \mathrm{~B}$ ). In contrast, formulated A. sylvatica extract $(7.8$ eggs per fruit; $\mathrm{t}=1.66, \mathrm{df}=50.89 ; \mathrm{P}=0.1015)$ and formulated A. muricata extract (5.7 eggs per fruit; $\mathrm{t}=0.72, \mathrm{df}=55.79 ; \mathrm{P}=0.4698$ ) did not differ significantly from untreated artificial fruits (Figure $2 \mathrm{~B}$ ).

\section{Ovicidal effect (embryonic effects) of treatments on fertility}

In the dipping bioassay with artificial fruit, spinetoram caused the greatest reduction in egg viability of the treatments (2.33\%; Figure 3). However, the A. mucosa formulation (48.8\% egg viability), formulated A. muricata seed-extract (52.2\%), formulated A. sylvatica seed-extract (45.5\%) and limonoid-based bioinsecticide (43.3\%) resulted in a significant reduction in egg viability $(\mathrm{F}=60.88 ; \mathrm{df}=6,20 ; \mathrm{P}<0.0001)$ compared with the negative controls of water and tween + methanol + water $(81.3 \%$ and $80.7 \%$, respectively; Figure 3$)$. 
Figure 2. Average number of eggs laid by Zaprionus indianus females in artificial fruit with different treatments in a laboratory bioassay: (A) Sexually mature $Z$. indianus females were confined in cages containing one artificial fruit treated in a no-choice bioassay (no-choice bioassay); (B) Sexually mature $Z$. indianus females were confined in cages containing one treated artificial fruit and one untreated fruit (choice bioassay).
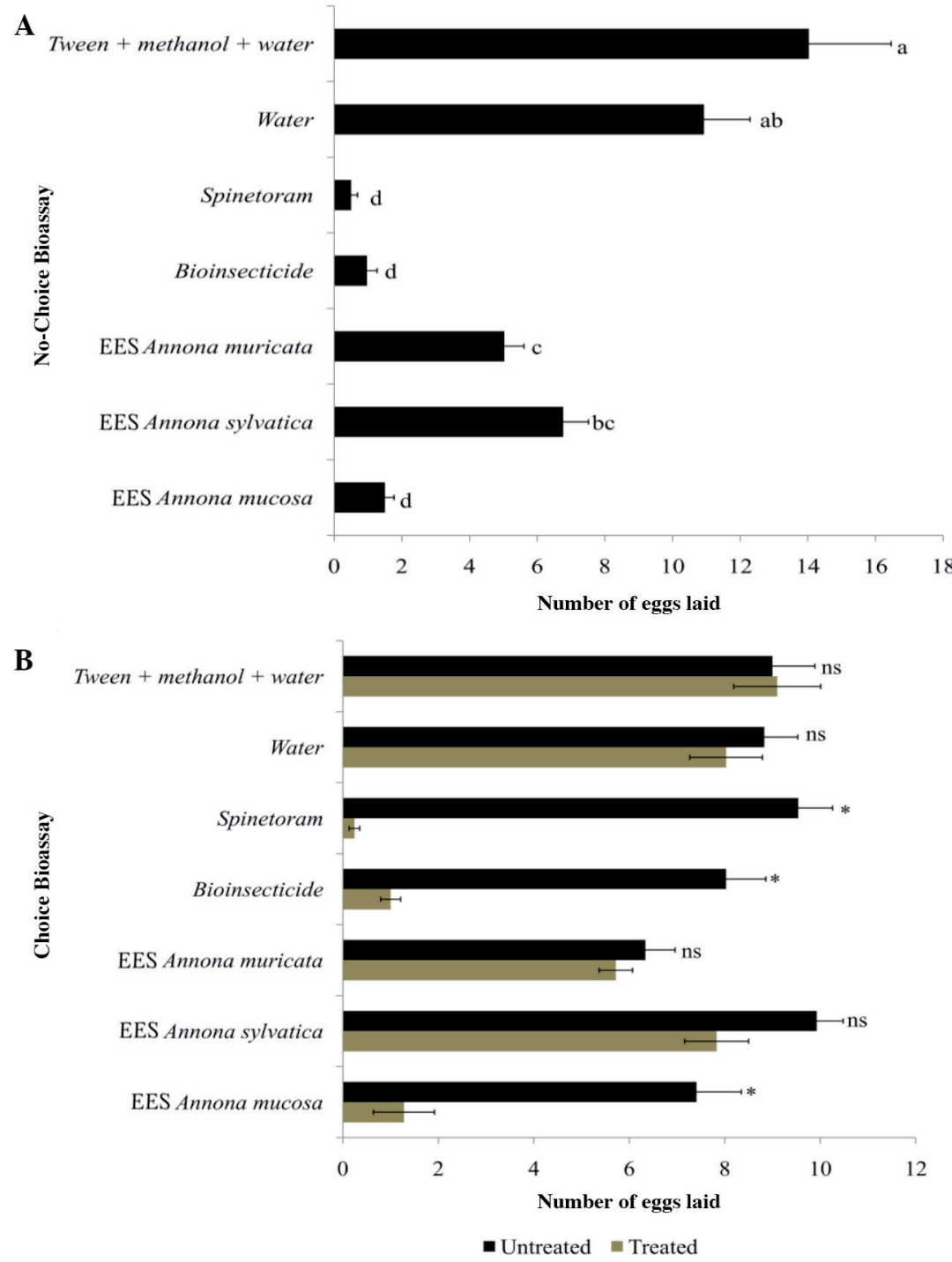

Means followed by the same letters in the columns did not differ significantly (generalized linear models with quasi poison distribution followed by Tukey's post hoc test $(\mathrm{P}<0.05)$. EES: Formulated ethanolic seed extract.

*Significant differences between treatments according to Student's t-test $(\mathrm{P}<0.05)$; ns: nonsignificant according to Student's t-test $(\mathrm{P}<0.05)$.

\section{Field experiment}

In the test conducted in a 'Roxo de Valinhos' fig orchard, the formulated A. mucosa at $2000 \mathrm{mg} \mathrm{L}^{-1}$ and limonoids-based insecticide caused a significant reduction $(\mathrm{F}=69.33$; $\mathrm{df}=3,26 ; \mathrm{P}<0.0001)$ in fruit infestation by $Z$. indianus compared to the negative control (Figure 4). However, the activity level of these treatments was lower than the positive control (spinetoram), in which only $1.43 \%$ of infested fruits were observed (Figure 4). This aspect reflected significantly ( $\mathrm{F}=35.62$; $\mathrm{df}=3,26 ; \mathrm{P}<0.0001)$ in a reduction in the number of $Z$. indianus larvae in fruits at harvest, with the extract formulated from seeds of A. тисова (3.6 larvae per fruit), the limonoid-based bioinsecticide (2.3 larvae per fruit) and spinetoram ( 0.71 larvae per fruit) being the most promising treatments (Figure 4). Again, the positive control represented by the insecticide spinetoram was the treatment that resulted in the most significant reduction in the number of larvae per fruit. 
Figure 3. Egg viability of Zaprionus indianus in a dipping bioassay with artificial fruit in the laboratory.

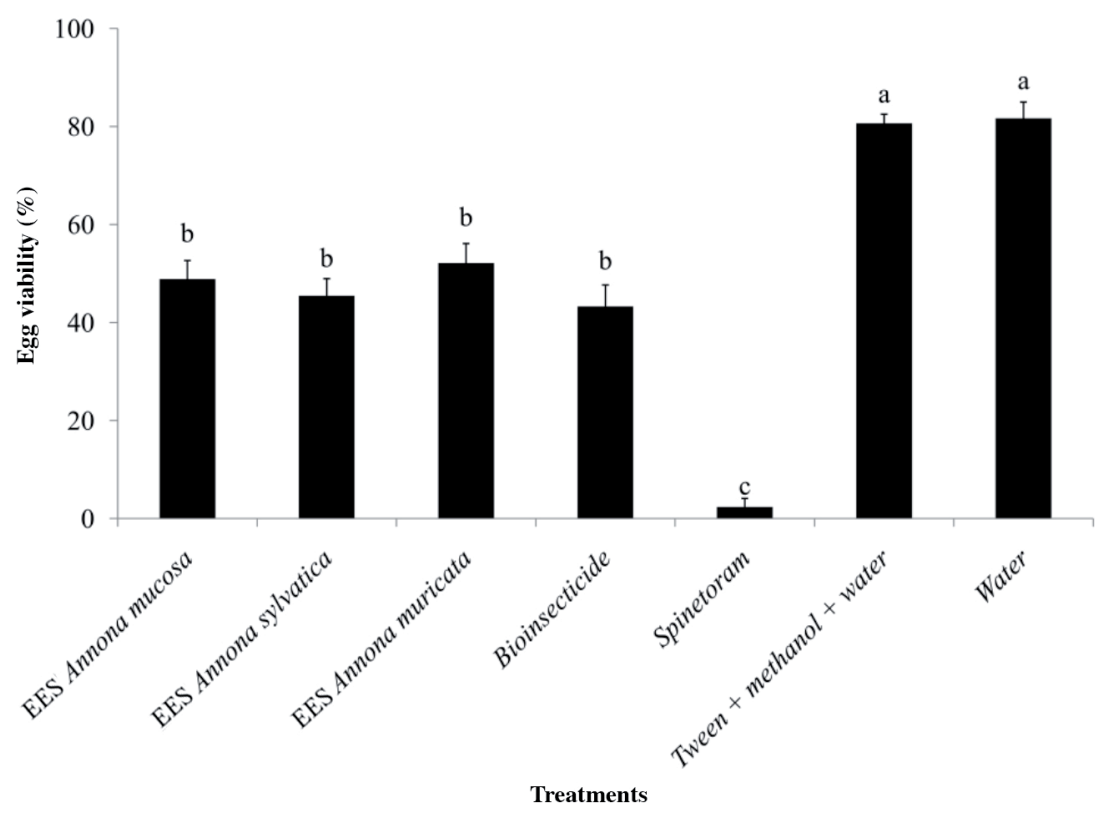

*Bars $( \pm$ SE) with the same letter are nonsignificantly different (generalized linear models with quasi-binomial distribution followed by Tukey's post hoc test; $\mathrm{P}<0.05)$. EES: Formulated ethanolic seed extract.

Figure 4. Means $( \pm$ SE) of percentage infested fruits and number of larvae per fruit after applying an aqueous emulsion of ethanolic extract from Annona mucosa seeds, a commercial limonoid-based bioinsecticide (Azamax 1.2 EC) and the spinosyn-based synthetic insecticide (Delegate 250 WG) in a test conducted in a commercial fig orchard.

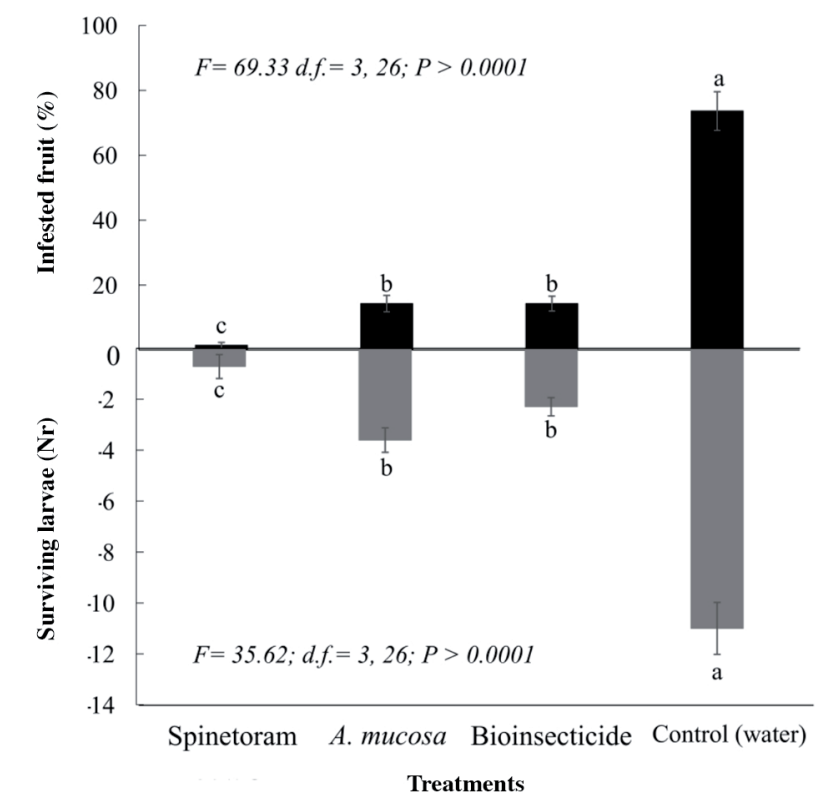

Means followed by the same letters in the columns did not differ significantly (generalized linear models with quasi-binomial distribution followed by Tukey's post hoc test; $\mathrm{P}<0.05)$. 


\section{DISCUSSION}

Our results, obtained under laboratory and field conditions, indicated the promising action of the A. mисosa formulation on $Z$. indianus, with a higher level of activity than that observed from the application of a commercial formulation based on limonoids and, in some cases, similar to the spinosyn-based insecticide, both used as positive controls. Several studies have demonstrated the toxicity of A. mucosa formulation to other pest species, including D. suzukii (Bernardi et al., 2017b), and Sitophilus zeamais (Motschulsky, 1855) (Coleoptera: Curculionidae) (Ribeiro et al., 2013). Thus, our results extend the spectrum of activity of the pre-commercial A. mucosa bioinsecticide and indicate the possibility of its application in a fig production system lacking registered insecticides and efficient management alternatives.

Our previous studies demonstrated that the bioactivity of A. тисоsa is due to the synergy of compounds from different chemical classes (especially acetogenins, alkaloids and triglycerides) and/or of different polarities, where bis-tetrahydrofuranic acetogenin rolliniastatin-1 is the major active component (Ribeiro et al., 2013). These molecules are inhibitors of complex I (NADH: ubiquinone oxidoreductase) in the mitochondrial electron transport system, with inhibition inducing cellular death (Audsley and Down, 2015). As most insecticides used in the control of Z. indianus act on acetylcholine receptors or on sodium channels (Casida and Durkin, 2013), the search for products with a different mode of action (e.g., acetogenins) may contribute to the management of resistant populations (Audsley and Down, 2015). Currently, no populations of $Z$. indianus resistant to insecticides have been reported. However, with high polyphagia, a short generation time and rapid dispersion (Joshi et al., 2014), associated with the continued use of insecticides, the selection pressure is high for the appearance of resistant populations (Haye et al., 2016).

In addition to the lethal toxicity of A. mисоs a formulation on Z. indianus in ingestion bioassays and topical application, promising oviposition effects have also been found, as well as for the bioinsecticides based on limonoids and spinosyn. These sublethal effects may affect the population density of $Z$. indianus and this was observed in the field experiments, where fig fruits were sprayed with such treatments and showed a significant reduction in the percentage of infested fruits and, consequently, the number of larvae per fruit. Thus, its combining effects on oviposition combined with adult mortality could be an important part of an IPM program, where the deterrence of oviposition is beneficial because of the negative effect on the population dynamics in future generations (Haye et al., 2016).

The extracts prepared from A. muricata and A. sylvativa seeds, as well as the formulation based on limonoids purified from neem, showed low toxicity to Z. indianus. However, they caused a repellency effect by reducing the capacity of female oviposition by up to $50 \%$, corroborating the field results for limonoid-based bioinsecticide and results observed with other pest species (Ribeiro et al., 2015; Bernardi et al., 2017a). Furthermore, products that decrease oviposition in Z. indianus reduce the incidence of epidermis rupture by oviposition, which consequently reduces infestation by pathogens that increase the processes of fruit decay (Van Timmeren and Isaacs, 2013).

Although some synthetic insecticides, including organophosphates and pyrethroids, are highly toxic to Z. indianus (Andreazza et al., 2017), the use of such products can leave chemical residues on fruits and are not registered for use in the management of this pest species in Brazil. There is a particular concern about these residues when the insecticides are applied during the pre-harvest and fruit-ripening periods, which are the periods most preferred for infestation by Z. indianus (Bernardi et al., 2017a). Thus, given the ease of production and rapid degradation and low residual effect (Ribeiro et al., 2015), formulations based on A. mисоsa seed extracts can be an additional tool for use in the management of $Z$. indianus, as observed with $D$. suzukii by Bernardi et al. (2017b). In addition, the formulation based on the extract of A. mucosa caused low toxicity in the Trichopria anastrephae parasitoid, which is considered the most common pupal parasitoid in the main fruit production areas in Brazil (Bernardi et al., 2017a), and entomopathogenic species of fungi with wide natural occurrence in orchards or even used in microbial pest control programs (Ribeiro et al., 2014).

Despite the commercial availability of Annonaceae-derived products in Eastern countries (Anosom, AnonaCin and Bio-Rakshak), the greatest species diversity is found in Brazil, many of which are widely grown on commercial scales and seeds considered an agroindustrial residue (Isman and Grieneisen, 2014; Ribeiro et al., 2014). The use of these residues in the preparation of new bio-insecticides can transform problems into more environmentally-suitable solutions for agriculture. 


\section{CONCLUSIONS}

In the light of ours findings, the formulation prepared from ethanolic seed-extract of Annona mucosa can be a useful and a promising component for the management of Zaprionus indianus, particularly in organic or low residue production systems.

\section{ACKNOWLEDGEMENTS}

The authors thank the Brazilian Federal Agency for Support and Evaluation of Graduate Education (CAPES) for financial support and scholarships conceived - Financing Code 001.

\section{REFERENCES}

Andreazza, F., Bernardi, D., Baronio, C.A., Pasinato, J., Nava, D.E., and Botton, M. 2017. Toxicities and effects of insecticidal toxic baits to control Drosophila suzukii and Zaprionus indianus (Diptera: Drosophilidae). Pest Management Science 73:146-152.

Audsley, N., and Down, R.E. 2015. G protein coupled receptors as targets for next generation pesticides. Insect Biochemistry and Molecular Biology 67:27-37.

Bernardi, D., Andreazza, F., Botton, M., Baronio, C.A., and D.E. Nava. 2017a. Susceptibility and interactions of Drosophila suzukii and Zaprionus indianus (Diptera: Drosophilidae) in damaging strawberry. Neotropical Entomology 46:1-7.

Bernardi, D., Ribeiro, L.P., Andreazza, F., Neitzke, C., Oliveira, E.E., Botton, M., et al. 2017b. Potential use of Annona by products to control Drosophila suzukii and toxicity to its parasitoid Trichopria anastrephae. Industrial Crops and Products 110:30-35.

Casida, J.E., and Durkin, K.A. 2013. Neuroactive insecticides: targets, selectivity, resistance, and secondary effects. Annual Review of Entomology 58:99-117.

Commar, L.S., Galego, L.G.D., Ceron, C.R., and Carareto, C.M.A. 2012. Taxonomic and evolutionary analysis of Zaprionus indianus and its colonization of Palearctic and Neotropical regions. Genetics and Molecular Biology 35:395-406.

Finney, D.J. 1971. Probit analysis. $3^{\text {rd }}$ ed. Cambridge University Press, Cambridge, UK.

Goncalves, G.L.P., Ribeiro, L.P., Gimenes, L., Vieira, P.C., Silva, M.F.G.F., Forim, M.R., et al. 2015. Lethal and sublethal toxicities of Annona sylvatica (Magnoliales: Annonaceae) extracts to Zabrotes subfasciatus (Coleoptera: Chrysomelidae: Bruchinae). Florida Entomologist 98:921-928.

Haye, T., Girod, P., Cuthbertson, A.G.S., Wang, X.G., Daane, K.M., Hoelmer, K.A., et al. 2016. Current SWD IPM tactics and their practical implementation in fruit crops across different regions around the world. Journal of Pest Science 89:643-651.

Hikal, W.M., Baeshen, R.S., and Said-Al Ahl, H.A.H. 2017. Botanical insecticide as simple extractives for pest control. Cogent Biology 3:1404274.

Isman, M.B., and Grieneisen, M.L. 2014. Botanical insecticide research: many publications, limited useful data. Trends in Plant Science 19:140-145.

Joshi, N.K., Biddinger, D.J., Demchak, K., and Deppen, A. 2014. First report of Zaprionus indianus (Diptera: Drosophilidae) in commercial fruits and vegetables in Pennsylvania. Journal of Pest Science 14:259-263.

Lasa, R., and Tadeo, E. 2015. Invasive drosophilid pests Drosophila suzukii and Zaprionus indianus (Diptera: Drosophilidae) in Veracruz, Mexico. Florida Entomologist 98:987-988.

Oulhaci, C.M., Denis, B., Kilani-Morakchi, S., Sandoz, J.C., Kaiser, L., Joly, D., et al. 2018. Azadirachtin effects on mating success, gametic abnormalities and progeny survival in Drosophila melanogaster (Diptera). Pest Management Science 74:174-180.

Pasini, M.P.B., Link, D., e Fronza, D. 2011. Eficácia de atrativos alimentares na captura de Zaprionus indianus (Gupta) em pomar de figo em Santa Maria - RS. EntomoBrasilis 4:56-60.

R Development Core Team. 2012. R: A language and environment for statistical computing. R Foundation for Statistical Computing, Vienna, Austria. Available at https://www.R-project.org/.

Raga,A., Souza Filho, M.F., e Sato, M.E. 2003. Eficiência de protetores de ostíolo do figo sobre a infestação da mosca Zaprionus indianus (Gupta) (Diptera: Drosophilidae) no campo. Arquivo Instituto Biológico 70:287-289.

Ribeiro, L.P., Mota, L.H.C., D’Alessandro, C.P., Vendramim, J.D., and Delalibera Júnior, I. 2014. In vitro compatibility of an acetogenin-based bioinsecticide with three species of entomopathogenic fungi. Florida Entomologist 97:1395-1403.

Ribeiro, L.P., Santos, M.S., Gonçalves, G.L.P., and Vendramim, J.D. 2015. Toxicity of an acetogenin-based bioinsecticide against Diaphorina citri (Hemiptera: Liviidae) and its parasitoid Tamarixia radiata (Hymenoptera: Eulophidae). Florida Entomologist 98:835-842. 
Ribeiro, L.P., Vendramim, J.D., Bicalho, K.U., Andrade, M.S., Fernandes, J.B., Moral, R.A., et al. 2013. Annona mucosa Jacq. (Annonaceae): a promising source of bioactive compounds against Sitophilus zeamais Mots (Coleoptera: Curculionidae). Journal of Stored Products Research 55:6-14.

Ribeiro, L.P., Vendramim, J.D., Gonçalves, G.P., Ansante, T.F., Gloria, E.M., Lopes, J.C., et al. 2016. Searching for promising sources of grain protectors in extracts from Neotropical Annonaceae. Boletín Latinoamericano y del Caribe de Plantas Medicinales y Aromáticas 15:215-232.

SAS Institute. 2011. Statistical analysis system: Getting started with the SAS learning. 92 ed. SAS Institute, Cary, North Carolina, USA.

Schlesener, D.C.H., Wollann, J., Kruger, A.P., Martins, L.N., Geisler, F.C., and Garcia, F.R.M. 2017. Rearing method for Drosophila suzukii and Zaprionus indianus (Diptera: Drosophilidae) on artificial culture media. Drosophila Information Service 100:185-189.

Van Timmeren, S., and Isaacs, R. 2013. Control of spotted wing drosophila, Drosophila suzukii, by specific insecticides and by conventional and organic crop protection programs. Crop Protection 54:126-133. 